\title{
PHYLOGEOGRAPHY OF SESAMIA NONAGRIOIDES (LEPIDOPTERA: NOCTUIDAE) IN IRAN INFERRED FROM MITOCHONDRIAL DNA
}

\author{
Mehdi Esfandiari ${ }^{1}$, Neda Mehravar ${ }^{2}$, Hossein Motamedi ${ }^{2}$ \\ Hamid Rajabi Memari ${ }^{3}$ and Hossein Rajaei ${ }^{4}$ \\ ${ }^{1}$ Department of Plant Protection, College of Agriculture, Shahid Chamran University of Ahvaz \\ Ahvaz, Iran; E-mail: apameini@yahoo.com \\ ${ }^{2}$ Departments of Biology, College of Science, Shahid Chamran University of Ahvaz, Ahvaz, Iran; \\ E-mail: mehravar86@yahoo.com; hhmotamedi@yahoo.com \\ ${ }^{3}$ Department of Agronomy and Plant Breeding, College of Agriculture, Shahid Chamran \\ University of Ahvaz, Ahvaz, Iran; E-mail: hamidmemary@gmail.com \\ ${ }^{4}$ State Museum of Natural History, Rosenstein 1, 70191 Stuttgart, Germany \\ E-mail: hossein.rajaei@smns-bw.de
}

\begin{abstract}
Although the stem borer Sesamia nonagrioides (Lefèbvre, 1827) is one of the most destructive agricultural pests in South and Southwest Iran, the structure of these populations is not yet well understood. In this study, we sequenced two mitochondrial genes (CO1 and Cyt- $b$ ) of populations collected in cultivated sugarcane and rice in South and Southwest Iran. These genetic data of Iranian populations were compared with those of already published data from West Palaearctic (Africa and Europe). To testing the intra- and inter-population variations, different population analyses (e.g. haplotype network, haplotype and nucleotide diversity) were executed. Our results indicate a considerable genetic variation in Iranian populations of $S$. nonagrioides, which supports the long-term establishment of S. nonagrioides populations in Iran versus a recent invasion. Close genetic relationship of Iranian population of S. nonagrioides with a population of Central Ethiopia supports the scenario of the origin of this species from Africa to western Asia through the Trans-Arabian bridge. Our results help to explain the variation in pest status of $S$. nonagrioides observed across its distribution range in Iran.
\end{abstract}

Key words: CO1, Cyt- $b$, gene flow, haplotype, population genetics.

\section{INTRODUCTION}

The stem borer Sesamia nonagrioides (Lefèbvre, 1827) (Lepidoptera: Noctuidae) is one of the most damaging sugarcane pests in sugarcane agro-industries of Khuzestan province (Southwest Iran) since 1950's. It is also a pest of maize and rice in provinces of Khuzestan and Fars (South Iran) where it completes four to five generations annually (Khanjani 2004, Cherghali et al. 2015). The pest status of $S$. nonagrioides on different crops varies across its distribution range in Iran (Cherghali et al. 2015). Pest management strategies of this economic pest in sugarcane fields of south-western Iran include releasing the egg parasitoid wasp Telenomus busseolae Gahan (Hym., Scelionidae) (JAmsHidnia et al. 2010). However, this wasp cannot perform a successful biologi- 
cal control of the pest especially during hot summers in Khuzestan province or in sensitive sugarcane varieties (JAmshidnia, pers. comm.). Pesticides are used by farmers in the case of heavy damage to maize and rice. Management practices of $S$. nonagrioides in Iran ignore the possible existence of genetic diversity among populations of this pest and its range of distribution.

The species $S$. nonagrioides, is considered one of the most important pests of maize in many countries around the Mediterranean region where it is known as the Mediterranean corn borer or corn stalk borer (De LA PozA et al. 2008). This pest has been traditionally regarded as a rather sedentary pest (AlBAJES et al. 2004, Eizaguirre et al. 2004, Margaritopoulos et al. 2007), likely to develop genetic isolation between geographical regions. Genetic differentiation between S. nonagrioides populations in European countries has been reported using different molecular markers (Bues et al. 1996, Kourti 2006, Leniaud et al. 2006, Margaritopoulos et al. 2007, De La Poza et al. 2008). Moyal et al. (2011) reconstructed the evolutionary history of Palaearctic and Sub-Saharan populations of $S$. nonagrioides using one nuclear and two mitochondrial genes and concluded that the isolated Iranian population appears to have recently originated from a population of eastern Europe origin.

Sesamia nonagrioides seems not to be a recently introduced pest, but changed from wild host plants to cultivated sugarcane during the first establishment of sugarcane agro-industries in south-western Iran in 1950's (EsfanDIARI et al. 2011a, b). CHERghali et al. (2015) found a considerably high genetic variation with Random Amplified Polymorphic DNA (RAPD) among Iranian S. nonagrioides populations which supported the "host-plant switching" hypothesis versus the recent invasion of $S$. nonagrioides by infested sugarcane cuttings to Iran. Concerning the disadvantages of RAPD (SCHLÖTtERER 2004), a deeper understanding of the population genetic structure of this pest could greatly benefit management decisions related to this species in Iran (e.g. improve monitoring and biological control strategies). In the present article, we used mitochondrial DNA (mtDNA) sequences of cytochrome $b$ (Cyt- $b$ ) and cytochrome $c$ oxidase, subunit 1 (CO1) to evaluate the population structure and genetic variability of the stem borer $S$. nonagrioides in Iran. These details were further analysed with sequences available in NCBI GenBank from those already published from West Palaearctic (Africa and Europe) (Moyal et al. 2011).

\section{MATERIAL AND METHODS}

Sampling - Specimens of S. nonagrioides were collected across its area of distribution in Iran from infested host plants of sugarcane and rice in three main locations (Table 1): Hafttappeh and Imam Khomeini agro-industries in North Khuzestan, Amir Kabir agro-industry in South Khuzestan and Firuzabad suburbs area in Fars. After collection, specimens were preserved in $96 \%$ ethanol and stored at $-20^{\circ} \mathrm{C}$ for DNA extraction. Specimens were identified by using identification keys (e.g. Tams \& Bowden 1953, Mejjerman \& Ulenberg 1996). 
Table 1. Locations of Sesamia nonagrioides collections from agricultural fields in south and south-west Iran and quantity of analysed specimens $(\mathrm{N})$.

\begin{tabular}{lllccc}
\hline Location & Province & Geocoordinate & Host plant & $\begin{array}{c}\text { Sampling } \\
\text { date }\end{array}$ & $\begin{array}{c}\text { N (CO1, } \\
\text { Cyt- } b)\end{array}$ \\
\hline Hafttappeh & Khuzestan & $32^{\circ} 05^{\prime} \mathrm{N}, 48^{\circ} 21^{\prime} \mathrm{E}$ & sugarcane & Aug. 2011 & 6,6 \\
Imam Khomeini & Khuzestan & $31^{\circ} 47^{\prime} \mathrm{N}, 48^{\circ} 43^{\prime} \mathrm{E}$ & sugarcane & Oct. 2013 & 5,4 \\
Amir Kabir & Khuzestan & $31^{\circ} 03^{\prime} \mathrm{N}, 48^{\circ} 18^{\prime} \mathrm{E}$ & sugarcane & Jun. 2007 & 8,9 \\
Firuzabad & Fars & $2^{\circ} 00^{\prime} \mathrm{N}, 52^{\circ} 33^{\prime} \mathrm{E}$ & rice & Sept. 2011 & 4,4 \\
\hline
\end{tabular}

DNA extraction, PCR amplification and sequencing - DNA was isolated mostly from last instar larvae and in some cases from adults. Total genomic DNA was extracted from the head and thorax of each specimen using the DNeasy Blood \& Tissue Kit (QIAGEN GmbH) following the manufacturer's protocol for insects. Two mitochondrial genes Cytochrome $c$ oxidase subunit 1 (CO1) and Cytochrome b (Cyt-b) were amplified. For amplifying Cyt- $b$ with nested PCR procedure, two primer pairs obtained from Moyal et al. (2011) were used. External primers were TRs (5'-TCTATCTTATGTTTTCAAAAG-3') and CP1 (5'-GATGATGAAATTTTGGATC-3') while internal primers were CB3H (5'AGCAAATAAAAAATATCATTC-3') and CB1 (5'TATGTACTACCATGAGGACAAATATC-3'). The products of internal primers were used for sequencing. Fragment of $\mathrm{CO} 1$ was amplified by primers Hobbes (5' AAATGTTGNGGRAAAAATGTTA-3') and Ron (5'-GGATCACCTGATATAGCATTCC-3') (Moyal et al. 2011). The PCR reaction was performed in a total volume of 25 $\mu \mathrm{l}$ containing $2.5 \mu \mathrm{l}$ PCR buffer 10X, $1.5 \mu \mathrm{l} \mathrm{Mgcl}, 50 \mathrm{mM}, 0.5 \mu \mathrm{l}$ dntp $10 \mathrm{mM}, 1 \mu \mathrm{l}$ of each primer $10 \mu \mathrm{M}, 2$ unit of Taq DNA polymerase (CinnaGen technologies-Iran) and $2 \mu \mathrm{l}$ of extracted DNA (100-200 ng). The PCR program for the two genes was as follows: $92^{\circ} \mathrm{C}$ for $5 \mathrm{~min}, 35$ cycles of $1 \mathrm{~min}$ at $92^{\circ} \mathrm{C}, 1.3 \mathrm{~min}$ at temperature gradient from 40 to $50^{\circ} \mathrm{C}$ and 1.3 at $72^{\circ} \mathrm{C}$, followed by $5 \mathrm{~min}$ at $72^{\circ} \mathrm{C}$. The PCR products were visualized by means of electrophoresis in $1 \%$ agarose gel. Sequencing was performed mainly with an ABI3730XL capillary sequencer (Macrogen, Seoul, Korea).

Data analyses - Nucleotide sequences of Cyt- $b$ and CO1 of additional S. nonagrioides specimens from the study by Moyal et al. (2011) were obtained from GenBank (NCBI) (Table 2). Sequences were edited in BioEdit 7.1.3 (Hall 1999) and successfully aligned with MAFFT 6 (КАтон et al. 2002) by using default settings. All sequences were deposited in GenBank (accession numbers KT583674-KT583719, see supplementary table). Statistical parsimony networks of $\mathrm{CO} 1$ and $\mathrm{Cyt}-b$ for populations of $S$. nonagrioides were reconstructed with TCS v.1.3 (CLEMENT et al. 2000). This analysis separated the sequences into a network of closely related haplotype groups (with connected branches with less than $95 \%$ probability). Population diversity indices including haplotype diversity $(h)$, nucleotide diversity $(\pi)$ (NeI \& Miller 1990) and $\mathrm{F}_{\mathrm{st}}$ for each population of $S$. nonagrioides were calculated using Arlequin 3.5.1.2 (Excoffier \& Lischer 2010). The results of analyses of molecular variation (AMOVA) were visualized using a script of $\mathrm{R}$ statistic program integrated in the Arlequin.

\section{RESULTS}

Sequence variation - In total, $653 \mathrm{bp}$ of CO1 mtDNA of 59 individuals and $369 \mathrm{bp}$ of Cyt- $b \mathrm{mtDNA}$ of 62 individuals of $S$. nonagrioides were successfully aligned and analysed from Iran (Table 1), Europe and Africa (Table 2). 
Table 2. Analysed sequences of Sesamia nonagrioides with sampling site details obtained from NCBI GenBank accession numbers (JF274085-JF274205) and quantity of analysed specimens $(\mathrm{N})$.

\begin{tabular}{lccc}
\hline Country & $\mathrm{N}(\mathrm{CO} 1, \mathrm{Cyt}-b)$ & Locality & Geocoordinates \\
\hline Ivory Coast & $(2,8)$ & Abobo & $05^{\circ} 19^{\prime} \mathrm{N}, 04^{\circ} 01^{\prime} \mathrm{W}$ \\
Rwanda & $(1,3)$ & Kitikinyoni & $01^{\circ} 35^{\prime} \mathrm{S}, 29^{\circ} 36^{\prime} \mathrm{E}$ \\
Kenya & $(3,4)$ & Kisumu & $00^{\circ} 06^{\prime} \mathrm{S}, 34^{\circ} 19^{\prime} \mathrm{E}$ \\
& $(6,7)$ & Lwanda & $00^{\circ} 29^{\prime} \mathrm{S}, 34^{\circ} 18^{\prime} \mathrm{E}$ \\
& $(3,3)$ & Bogoria & $00^{\circ} 13^{\prime} \mathrm{N}, 36^{\circ} 02^{\prime} \mathrm{E}$ \\
Ethiopia & $(0,1)$ & Kiboko & $02^{\circ} 12^{\prime} \mathrm{S}, 37^{\circ} 42^{\prime} \mathrm{E}$ \\
& $(2,1)$ & Bahar Dar & $11^{\circ} 22^{\prime} \mathrm{N}, 37^{\circ} 14^{\prime} \mathrm{E}$ \\
& $(2,5)$ & Andasa & $11^{\circ} 18^{\prime} \mathrm{N}, 37^{\circ} 17^{\prime} \mathrm{E}$ \\
& $(1,0)$ & $07^{\circ} 03^{\prime} \mathrm{N}, 38^{\circ} 17^{\prime} \mathrm{E}$ \\
Turkey & $(2,4)$ & $06^{\circ} 06^{\prime} \mathrm{N}, 37^{\circ} 24^{\prime} \mathrm{E}$ \\
Greece & $(4,3)$ & Olack water & $07^{\circ} 02^{\prime} \mathrm{N}, 38^{\circ} 17^{\prime} \mathrm{E}$ \\
Spain & $(1,0)$ & $05^{\circ} 33^{\prime} \mathrm{N}, 37^{\circ} 19^{\prime} \mathrm{E}$ \\
France & $(1,0)$ & Awasa & $37^{\circ} 01^{\prime} \mathrm{N}, 35^{\circ} 19^{\prime} \mathrm{E}$ \\
& $(2,0)$ & Chamoleto & $41^{\circ} 05^{\prime} \mathrm{N}, 23^{\circ} 33^{\prime} \mathrm{E}$ \\
& $(1,0)$ & Adana & $41^{\circ} 37^{\prime} \mathrm{N}, 00^{\circ} 35^{\prime} \mathrm{E}$ \\
& $(1,0)$ & Serres & $44^{\circ} 23^{\prime} \mathrm{N}, 04^{\circ} 42^{\prime} \mathrm{E}$ \\
& $(2,0)$ & Lleida & $43^{\circ} 12^{\prime} \mathrm{N}, 02^{\circ} 20^{\prime} \mathrm{E}$ \\
& $(2,0)$ & Pierrelatte & $43^{\circ} 34^{\prime} \mathrm{N}, 04^{\circ} 42^{\prime} \mathrm{W}$ \\
\hline
\end{tabular}

The CO1 fragment contained 41 variable sites and revealed 35 haplotypes and Cyt- $b$ with 30 variable sites and 33 haplotypes (Fig. 1).

Population genetic analyses - The general pattern of haplotype and nucleotide diversities of both $\mathrm{CO} 1$ and Cyt- $b$ in the populations was highly similar. Unlike other Iranian populations, those from North Khuzestan showed no haplotype and nucleotide diversity in both genes (see Table 3). Haplotype and nucleotide diversities ranged from 0.0000 to 0.9960 and 0.000000 to 0.007687 for CO1, respectively (Table 3). These statistics ranged from 0.0000 to 0.9849 and 0.000000 to 0.010327 for Cyt- $b$, respectively (Table 3 ).

Fig. 1. Haplotype network based on partial mtDNA COI (A) and Cyt-b (B) of Sesamia nonagrioides analysed populations at the $95 \%$ level. Each haplotype is represented by a circle, and is identified by a number. Colors indicate representative populations and the size of the colored slices and circles is proportional to the number of individuals carrying the haplotype. Due to the low number of individuals per populations, all European countries (showed with Eu. in parenthesis) were pooled together in AMOVA analyses 

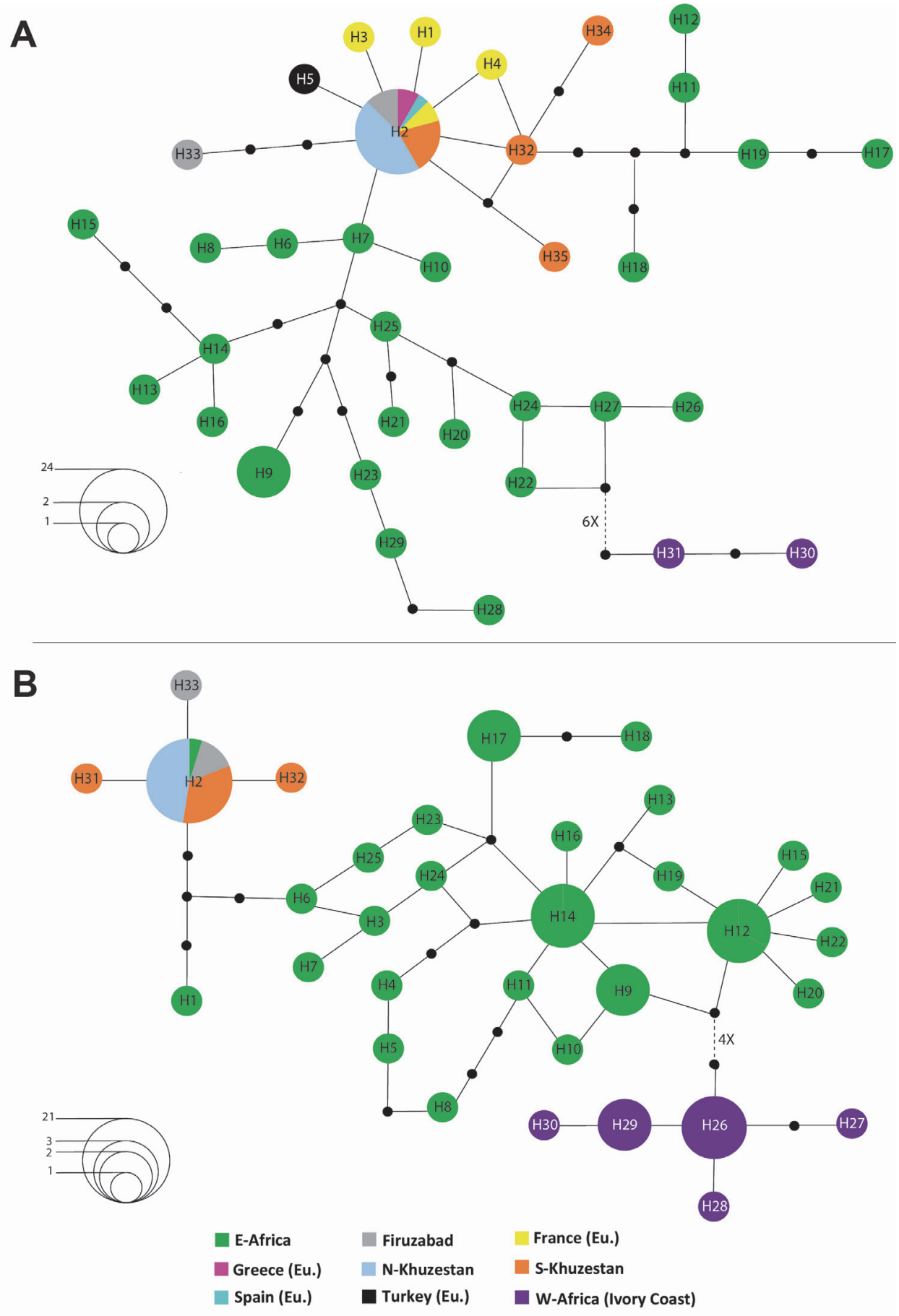
Table 3. Sampling sites, quantity of analysed specimens ( $n$ ), and identified CO1 and Cyt- $b$ haplotypes of the studied populations of Sesamia nonagrioides (H). Statistical parameters indicate haplotypic diversity $h($ mean $\pm S D)$ and nucleotide diversity $\pi($ mean \pm SD) observed for the CO1 and Cyt- $b$ fragments of the studied populations.

\begin{tabular}{llrrcc}
\hline Marker & & $\mathrm{n}$ & $\mathrm{H}$ & Haplotype diversity $(\mathrm{h})$ & Nucleotide diversity $(\pi)$ \\
\hline CO1 $^{*}$ & N Khuzestan & 11 & 1 & $0.0000 \pm 0.0000$ & $0.000000 \pm 0.000000$ \\
& S Khuzestan & 8 & 4 & $0.6429 \pm 0.1841$ & $0.002461 \pm 0.001849$ \\
& Firuzabad & 4 & 2 & $0.5000 \pm 0.2652$ & $0.002297 \pm 0.002050$ \\
& Europe & 9 & 5 & $0.7222 \pm 0.1592$ & $0.001361 \pm 0.001183$ \\
& East Africa & 25 & 24 & $0.9960 \pm 0.0142$ & $0.007687 \pm 0.004323$ \\
\hline${\text { Cyt }-b^{*}}^{*}$ & N Khuzestan & 10 & 1 & $0.0000 \pm 0.0000$ & $0.000000 \pm 0.000000$ \\
& S Khuzestan & 9 & 3 & $0.4167 \pm 0.1907$ & $0.001204 \pm 0.001333$ \\
& Firuzabad & 4 & 2 & $0.5000 \pm 0.2652$ & $0.001355 \pm 0.001680$ \\
& East Africa & 31 & 24 & $0.9849 \pm 0.0124$ & $0.010327 \pm 0.005942$ \\
& West Africa & 8 & 5 & $0.8571 \pm 0.1083$ & $0.004162 \pm 0.003160$ \\
\hline
\end{tabular}

*Not estimated for West Africa (in CO1) because only two sequences of CO1 were obtained in GenBank. Also not estimated for Europe (in Cyt- $b$ ) because no sequences were found in GenBank

The highest nucleotide diversity was recorded in East Africa population (CO1: 0.007687 \pm 0.004323 ; Cyt- $b: 0.010327 \pm 0.005942)$ while the lowest was observed in North Khuzestan population $(0.000000 \pm 0.000000$ for both genes). The lowest haplotype diversity was also recorded in North Khuzestan population $(0.000000 \pm 0.000000)$ for both CO1 and Cyt- $b$, while the highest value was recorded in East Africa population (CO1: 0.9960 \pm 0.0142 ; Cyt- $b$ : 0.9849 \pm 0.0124 ).

Fixation index $\left(\mathrm{F}_{\mathrm{ST}}\right)$ showed no significant genetic differentiation between Iranian populations according to both studied genes. The East African population showed significant difference with the Iranian populations in CO1. According to Cyt- $b$, both East and West African populations were also significantly different from the Iranian populations. The distances between

Table 4. Pairwise genetic differentiation $\left(\mathrm{F}_{\mathrm{ST}}\right)$ between studied populations of Sesamia nonagrioides for COI $(p \leq 0.05)$.

\begin{tabular}{lccccr}
\hline & N Khuzestan & S Khuzestan & Firuzabad & Europe & East Africa \\
\hline N Khuzestan & 0.00000 & & & & \\
S Khuzestan & 0.13177 & 0.00000 & & & \\
Firuzabad & 0.27072 & 0.02041 & 0.00000 & & \\
Europe & $0.02343^{*}$ & 0.04884 & 0.04202 & 0.00000 & \\
East Africa & $0.30873^{*}$ & $0.24301^{*}$ & $0.19016^{*}$ & $0.27430^{*}$ & 0.00000 \\
\hline
\end{tabular}

*indicates a significant value at the $5 \%$ level 
Table 5. Pairwise genetic differentiation $\left(\mathrm{F}_{\mathrm{ST}}\right)$ between studied populations of Sesamia nonagrioides for Cyt- $b(p \leq 0.05)$.

\begin{tabular}{lccccc}
\hline & N Khuzestan & S Khuzestan & Firuzabad & East Africa & West Africa \\
\hline N Khuzestan & 0.00000 & & & & \\
S Khuzestan & 0.01235 & 0.00000 & & & \\
Firuzabad & 0.24528 & 0.00907 & 0.00000 & & \\
East Africa & $0.47984^{*}$ & $0.46538^{*}$ & $0.41259^{*}$ & 0.00000 & \\
West Africa & $0.92141^{*}$ & $0.89186^{*}$ & $0.86405^{*}$ & $0.67750^{*}$ & 0.00000 \\
\hline
\end{tabular}

*indicates a significant value at the $5 \%$ level

West African population and Iranian populations were about two times more than between East African and Iranian populations. The two African populations were significantly different from each other (Tables 4 \& 5, Fig. 2).

Haplotype analyses - The relationships among mitochondrial haplotypes were reconstructed by haplotype networks for both CO1 and Cyt-b (Fig. 1). Only one haplotype ( $\mathrm{H} 2$, the most common haplotype in both networks) was traced from North Khuzestan. Apart from H2, the remaining haplotypes were each unique to one population. The phylogenetic analysis of CO1 gene revealed 35 haplotypes separated into two main clades. The first clade consists of individuals from Ivory Coast in West Africa and the second one included all other populations in which the Iranian populations were placed in the group close to the European populations. This group is close to some haplotypes of East Africa origin (from central Ethiopia). Haplotype 2 was well distributed and contained specimens from Firuzabad, North and South Khuzestan as well as from Europe.

In haplotype network of Cyt- $b, 33$ haplotypes showing similar pattern as $\mathrm{CO} 1$ and were separated in two main clades. The West African population from Ivory Coast separated (with 8 mutation steps in CO1 and 6 in Cyt-b) from other populations (Fig. 1). Haplotype H2 was well distributed and shared with Firuzabad, North and South Khuzestan. This haplotype was also found in East Africa.

\section{DISCUSSION}

The present study was an attempt to investigate the variation in mtDNA of $S$. nonagrioides, one of the most destructive agricultural pests in South and Southwest Iran. The results of both CO1 and Cyt- $b$ haplotype networks revealed that populations of $S$. nonagrioides in Iran are close or identical to those from Central Ethiopia, East Africa. Iranian S. nonagrioides populations also showed very close relationship with European population, but seemed to have higher diversification than the European population. 

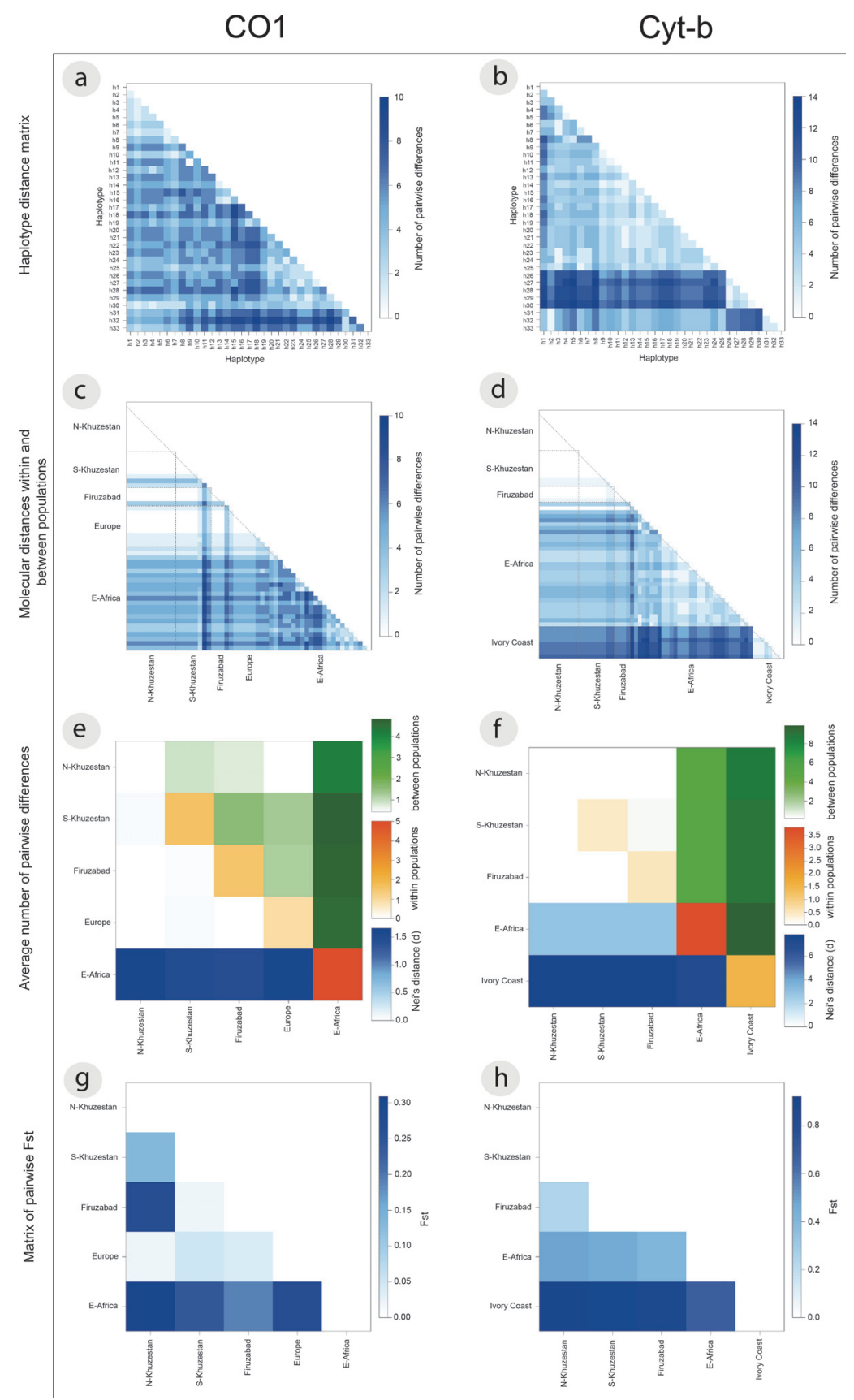

Fig. 2. Results of AMOVA for both studied genes of Sesamia nonagrioides. a and b: Haplotype distances matrix; $c$ and d: Nei's within and between population distances; e and f: number of pairwise differences between localities; $g$ and $h$ : comparison of $\mathrm{F}_{\text {st }}$ values of all populations 
Moyal et al. (2011) reconstructed the evolutionary history of Palaearctic and Sub-Saharan populations of $S$. nonagrioides using one nuclear and two mitochondrial genes. They found only two haplotypes among 54 sequences of Cyt- $b$ across southern Europe. In the present study we found 4 haplotypes among 23 sequences of Cyt- $b$ in South and Southwest Iran which may be indicative of higher diversification in Iranian (vs European) populations. However, CO1 was more diversified than Cyt- $b$ in the southern European populations and revealed 9 haplotypes among 65 sequences (Moyal et al. 2011). We found 5 haplotypes among 23 sequences of CO1 in Iran. Moreover, haplotype diversity index $(h)$ was also considerably higher in Iranian populations (Table 3) compared to European ones (Moral et al. 2011: table 2). This may support not only higher diversification, but also longer history of $S$. nonagrioides in Iran. It is worth saying that the sampling areas in southern Europe covered more geographical gradient and range of over $3000 \mathrm{~km}^{2}$, whereas in our study, sampling localities in South and Southwest Iran were limited to a distance of $500 \mathrm{~km}^{2}$.

Previous studies revealed high levels of differentiation among geographically close populations of $S$. nonagrioides, which could be indicative of the sedentary nature and moderate dispersal behavior of this pest, even when no remarkable geographical barriers exist (De La Poza et al. 2008, Moyal et al. 2011, Cherghali et al. 2015). Ecological observations regarding flight behavior and dispersal capacity of $S$. nonagrioides validate the low dispersal ability of this pest too (Albajes et al. 2004, Eizaguirre et al. 2004). In our study, only one haplotype of each CO1 and Cyt-b in Iranian populations were shared among localities (Fig. 1). Similar trend exists in African populations (Moyal et al. 2011: figs $1 \& 2$ ). This may also support the fact that $S$. nonagrioides is a fairly sedentary species. Personal observations of the first author have shown that during the cold season, plant stubbles and residues contain a large number of S. nonagrioides larvae. Most probably, the pest population in the farms comes from plant stubbles and residues at the same site rather than migrating from other areas.

It has been suggested that $S$. nonagrioides might be native to south-western Iran rather than an exotic recently imported pest, having adopted sugarcane as a host after its cultivation in Iran about 70 years ago (EsFandiari et al. 2011a, Cherghali et al. 2015). Sugarcane cultivation in Khuzestan was common since 2000 years ago until it became obsolescent about 600 years ago due to unknown reasons (AdAms 1962). High haplotype diversity in our result also support the hypothesis that the genetic structure of $S$. nonagrioides populations in Iran does not arise from a recent invasion of a common gene pool but may be due to a long time establishment with an ancient history. DANIALI (1985) reported some natural enemies such as the egg parasitoid Telenomus busseolae on S. nonagrioides in Khuzestan. Such natural enemies may have re- 
sulted in limited rapid population build-up of this species in the past, but the pest adopted sugarcane and other crops to outbreak in recent decades. Despite reports on infestation of wild host plants by this pest in Iran, especially Echinochloa colona in North Khuzestan (Daniali 1985), the stem borer seems to be uncommon in wild habitats. This could be attributed to poor nutritive value of wild plants.

Khuzestan sugarcane plantations and their environs are surrounded by two long rivers Karun and Karkheh and their tributaries. The main plants which inhabit such wetlands and tidal flats are reed species of Phragmites australis (CAV.) TRIN. Ex Steud and Typha angustifolia L. and sedges such as Juncus species (Hoberlandt 1983, LinNavuori 2009). Such plants may be the original wild host-plants of this insect before vast cultivations of sugarcane and cereals such as maize and rice in southern Iran. The preference of $S$. nonagrioides for sugarcane and severity of its damage in this crop suggest that it may be originally associated with wild species close to sugarcane in Iran.

Moyal et al. (2011) concluded that the isolated Iranian population appear to have recently originated from a population from Eastern Europe and does not belong to the Sub-Saharan sub-species $S$. nonagrioides botanephaga Tams et Bowden. Moyal et al. (2011) only included 2-4 Iranian individuals per gene from North Khuzestan (Hafttappeh and neighbouring areas). However, more individuals included in our study show no haplotype and nucleotide diversities in both $\mathrm{CO} 1$ and Cyt- $b$ haplotype networks (see Fig. 1). According to the results of haplotype network analyses in the present study, mitochondrial genes of Iranian population were identical to population of East Africa (individuals from Central Ethiopia), providing evidence for another plausible scenario for the spread of $S$. nonagrioides in the northeast part of its range. According to this scenario, this species may have spread into Southwest Iran through the Trans-Arabian bridge (as it also distributed in Yemen) and spread towards the north (northwest) along the Persian Gulf and also towards Europe. These populations had a stronger (more natural) genetic polymorphism, which was gradually lost during the spreading process (or not survived the subsequent crossing with the newly introduced, much less polymorphic populations). Moreover, the supposed natural reduction of polymorphism may explain the reduced haplotype diversity of the southern European population. In this case, the European population may have originated either from such pioneer populations expanding to the northern Mediterranean from East Africa (Arabian Peninsula) or from West Africa following a forceps-like colonisation. However, this scenario of unique colonization of the Palaearctic region from East Africa as suggested recently by KergoAt et al. (2015) requires more studies to be confirmed.

Larvae of S. nonagrioides, one of the most widespread noctuid stem borers, feed on many plants from different families such as Poaceae, Cyperaceae 
and Typhaceae (Daniali 1985, Jemsi \& Kamali 1992, Holloway 1998). Such plasticity in the feeding habit of this species has helped its expansion and more expansive species of the genus Sesamia occurring in subtropical and tropical Asia most probably had a similar spreading scenario with different routes towards the Himalayan region and the Pacific archipelago (LÁszló RonkAy, pers. comm.). The details of this expansion and the possible secondary and generally anthropogenic effects should be the aim of further studies and analyses.

Such genetic diversity found in this study may help explain the variation in pest status of the cereal stem borer S. nonagrioides observed across Iran. On the other hand, these results should be tested in other regions for the genome such as nuclear genes to increase our understanding of the genetic structure of this pest species in Iran.

Acknowledgements - We are appreciative to Pegah Soheilifar, Maryam Dadar and Bahareh Zaker Ghoran for their kind assistance in the molecular laboratory and Amir Cheraghi, Mahmoud Shomeili, Arsalan Jamshidnia, Marzieh Jalali, Masoomeh Afshar, Eng. Faqihi and Bizhan Naderpour for their kind support during field works and sampling. This project (\#101) was financially supported by the Shahid Chamran University of Ahvaz, Iran.

\section{REFERENCES}

Adams, R. M. (1962) Agriculture and urban life in early southwestern Iran. Science 136 (3511): 109-122. doi: 10.1126/science.136.3511.109

Albajes, R., Erar, J., Lopez, C., Ferran, X., Vigata, J. \& Eizaguire, M. (2004) Testing rubidium marking for measuring adult dispersal of the corn borer Sesamia nonagrioides: first results. IOBC/WPRS Bulletin 27(3): 15-22.

Bues, R., Eizaguire, M., Toubon, J. F. \& Albajes, R. (1996) Differences enzymatiques et ecophysiologiques entre populations de Sesamia nonagrioides Lefèbvre (Lepidoptera: Noctuidae) originaires de louest du Bassin Mediterraneen. Canadian Entomologist 128: 849-858. doi: 10.4039/ent128849-5

Cherghali, Z., Esfandiari, M., Mossadegh, M. S. \& Rajabi Memari H. (2015) Genetic diversity of populations of the stemborer Sesamia nonagrioides (Lepidoptera: Noctuidae) in south and south-west Iran, using RAPD-PCR. North-Western Journal of Zoology 11(1): 70-75.

Clement, M., Posada, D. \& Crandall, K. (2000) TCS: a computer program to estimate gene genealogies. Molecular Ecology 9 (10): 1657-1660. doi: 10.1046/j.1365-294x.2000.01020.x

DANIALI, M. (1985) Effect of biological, cultural and chemical control measures against sugarcane stem borers Sesamia spp. (Lep. Noctuidae) in Haft Tappeh, Khuzestan. MSc thesis, Shahid Chamran University, Ahvaz, Iran, 114 pp.

De la Poza, M., Farinos, P. G., Berioz, B., Ortego, F., Hernandez-Crespo, P. \& CasTANera, P. (2008) Genetic structure of Sesamia nonagrioides (Lefèbvre) populations in the Mediterranean area. Environmental Entomology 37(5): 1354-1360. doi: 10.1603/0046-225X(2008)37[1354:GSOSNL]2.0.CO;2 
Eizaguire, M., Lopez, C. \& Albajes, R. (2004) Dispersal capacity in the Mediterranian corn borer, Sesamia nonagrioides. Entomologia Experimentalis et Applicata 113: 25-34. doi: 10.1111/j.0013-8703.2004.00201.x

Esfandiari, M., Mossadegh, M. S. \& Shishehbor, P. (2011a) Sesamia botanephaga Tams \& Bowden, 1953 auct. in Iran, read Sesamia nonagrioides (Lefèbvre, 1827) (Lepidoptera: Noctuidae). Munis Entomology and Zoology 6(1): 400-403.

Esfandiari, M., Mossadegh, M. S. \& Shishehbor, P. (2011b) Noctuidae s.l. (Lepidoptera) from sugarcane fields of SW Iran. Fragmenta Faunistica 54(2): 137-147. doi: 10.3161/00159301FF2011.54.2.137

Excoffier, L. \& Lischer H. E. L. (2010) Arlequin ver. 3.5: a new series of programs to perform population genetics analyses under Linux and Windows. Molecular Ecology Resources 10: 564-567. doi: 10.1111/j.1755-0998.2010.02847.x

HALL, T. A. (1999) BioEdit: a user-friendly biological sequence alignment editor and analysis program for Windows 95/98/NT. Nucleic Acids Symposium Series 41: 95-98.

Holloway, J. D. (1998) Noctuidae: introduction. Pp. 79-86. In: PolazseK, A. (ed.): African cereal stem borers, economic importance, taxonomy, natural enemies and control. CAB International, Wallingford.

Hoberlandt, L. (1983) Results of the Czechoslovak-Iranian entomological expedition to Iran. Introduction to the third expedition 1977. Acta Entomologica Musei Nationalis Pragae 41: 5-24.

Jamshidnia, A., Kharazi-Pakdel, A., Allahyari, H. \& Soleymannejadian, E. (2010) Functional response of Telenomus busseolae (Hym.: Scelionidae) an egg parasitoid of the sugarcane stem borer, Sesamia nonagrioides (Lep.: Noctuidae) at different temperatures. Biocontrol Science and Technology 20(6): 631-640. doi: 10.1080/09583151003695902

Jemsi, GH. \& Kamali, K. (1992) Biology, host range and damage of corn stem borer in Khuzestan. Applied Entomology and Phytopathology 59(1-2): 31-33.

Katoh, K., Misawa, K., Kuma, K. \& Miyata, T. (2002) MAFFT: a novel method for rapid multiple sequence alignment based on fast Fourier transform. Nucleic Acids Research 30: 3059-3066. doi: 10.1093/nar/gkf436

Kergoat, G. J., Toussaint, E. F. A., Capdevielle-Dulac, C., Clamens, A.-L., Ong'Amo, G., Conlong, D., Van Den Berg, J., Cugala, D., Pallangyo, B., Mubenga, O., Chipabika, G., Ndemah, R., Sezonlin, M., Bani, G., Molo, R., Ali, A., Calatayud, P.-A., Kaiser, L., Silvain, J.-F., Le Ru, B. (2015) Integrative taxonomy reveals six new species related to the Mediterranean corn stalk borer Sesamia nonagrioides (Lefèbvre) (Lepidoptera, Noctuidae, Sesamiina). Zoological Journal of the Linnean Society 175(2): 244-270. doi: 10.1111/zoj.12275

Khanjani, M. (2009) Field crop pests in Iran. Bu-Ali Sina University Press, Hamadan, 738 pp.

KourTI, A. (2006) Mitochondrial DNA restriction map and cytochrome c oxidase subunits I and II sequence divergence of corn stalk borer Sesamia nonagrioides (Lepidoptera: Noctuidae). Biochemical Genetics 44: 321-331. doi: 10.1007/s10528-006-9032-3

Linnavuori, R. E. (2009) Studies on the Nepomorpha, Gerromorpha, Leptopodomorpha and Miridae excluding Phylini (Hemiptera: Heteroptera) of Khuzestan and the adjacent provinces of Iran. Acta Entomologica Musei Nationalis Pragae 49(1): 1-32.

Leniaud, L., Audiot, P., Bourguet, D., Ffrérot, B., Genestier, G., Fai Lee, S., Malausa, T., Le Pallec, A.-H., Souqual, M.-C. \& Ponsard, S. (2006) Genetic structure of European and Mediterranean maize borer populations on several wild and cultivated host plants. Entomologia Experimentalis et Applicata 120: 51-62. doi: 10.1111/j.15707458.2006.00427.x 
Margaritopoulos, J. T., Gotosopoulos, B., Mamuris, Z., Skouras, P. J., Voudouris, K. C., Bacandritsos, N., Fantinou, A. A. \& Tsitsipis, J. A. (2007) Genetic variation among Mediterranean populations of Sesamia nonagrioides as revealed by RFLP mtDNA analysis. Bulletin of Entomological Research 97: 299-308. doi: 10.1017/S000748530700507X

Meijerman, L. \& Ulennerg, S. A. (1996) Identification of African stem borer larvae (Lepidoptera: Noctuidae, Pyralidae) based on morphology. Bulletin of Entomological Research 86: 567-578. doi: 10.1017/S0007485300039365

Moyal, P., Torko, P., Bayram, A., Savopoulou-Soultani, M., Conti, E., Eizaguierre, M., Le Ru, B., Avand-Faghin, A., Frerot, B. \& Andreadis, S. (2011) Origin and taxonomic status of the Palearctic population of the stem borer Sesamia nonagrioides (Lefebvre) (Lepidoptera: Noctuidae). Biological Journal of the Linnean Society 103: 904-922. doi: 10.1111/j.1095-8312.2011.01666.x

Nei, M. \& Miller, S. C. (1990) A simple method for estimating average number of nucleotide substitutions within and between populations from restriction data. Genetics 125: 873-879.

SChlötterer, C. (2004) The evolution of molecular markers - just a matter of fashion? Nature Reviews Genetics 5: 63-69. doi: 10.1038/nrg1249

Tams, W. H. T. \& Bowden, J. (1953) A revision of the African species of Sesamia Guenée and related genera (Agrotidae-Lepidoptera). Bulletin of Entomological Research 43: 645-679. doi: 10.1017/S0007485300026717

Revised version received September 6, 2014, accepted August 27, 2015, published October 19,2015 


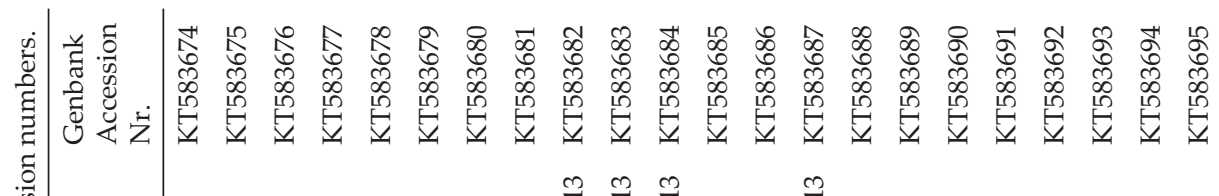

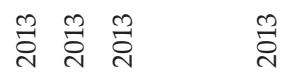

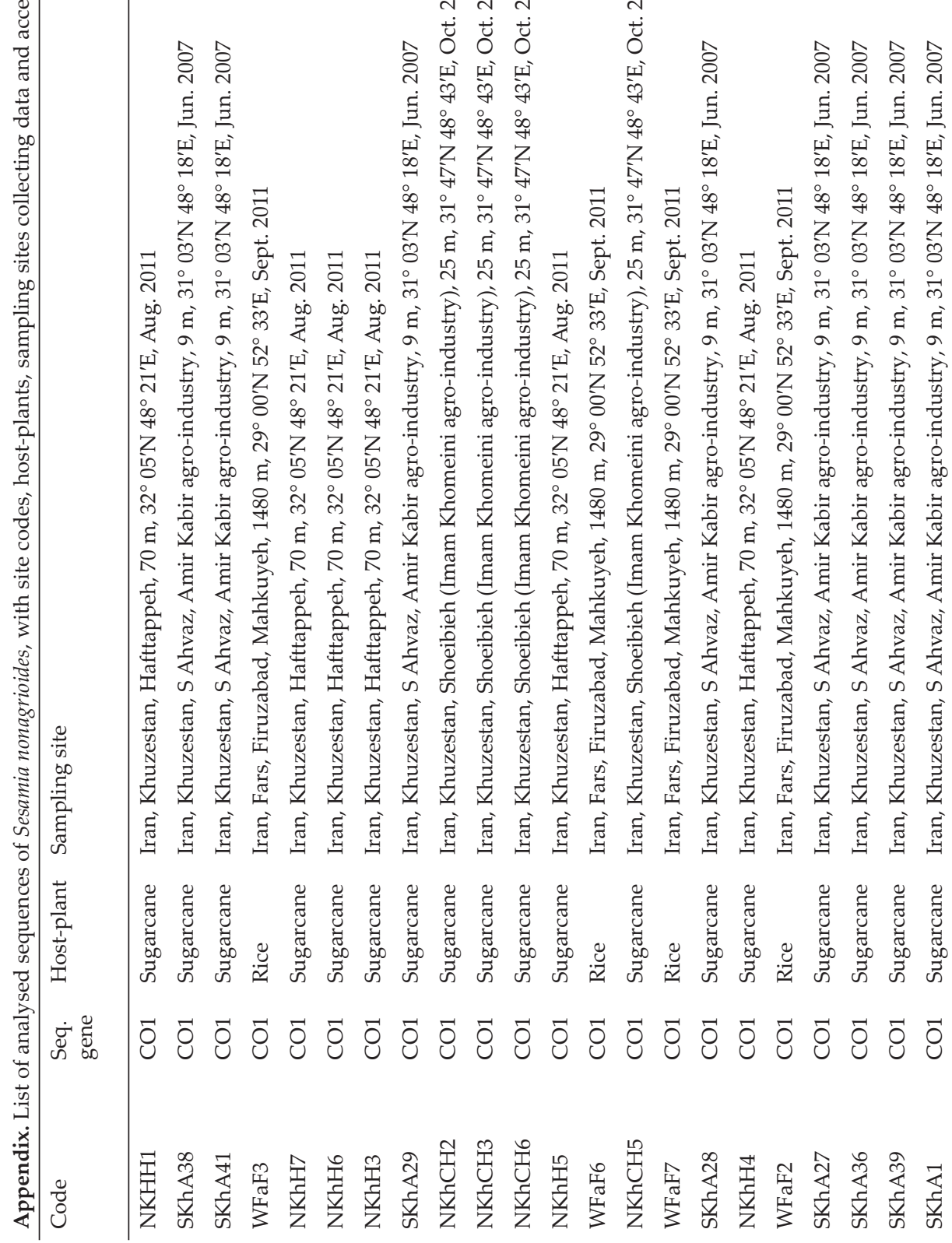




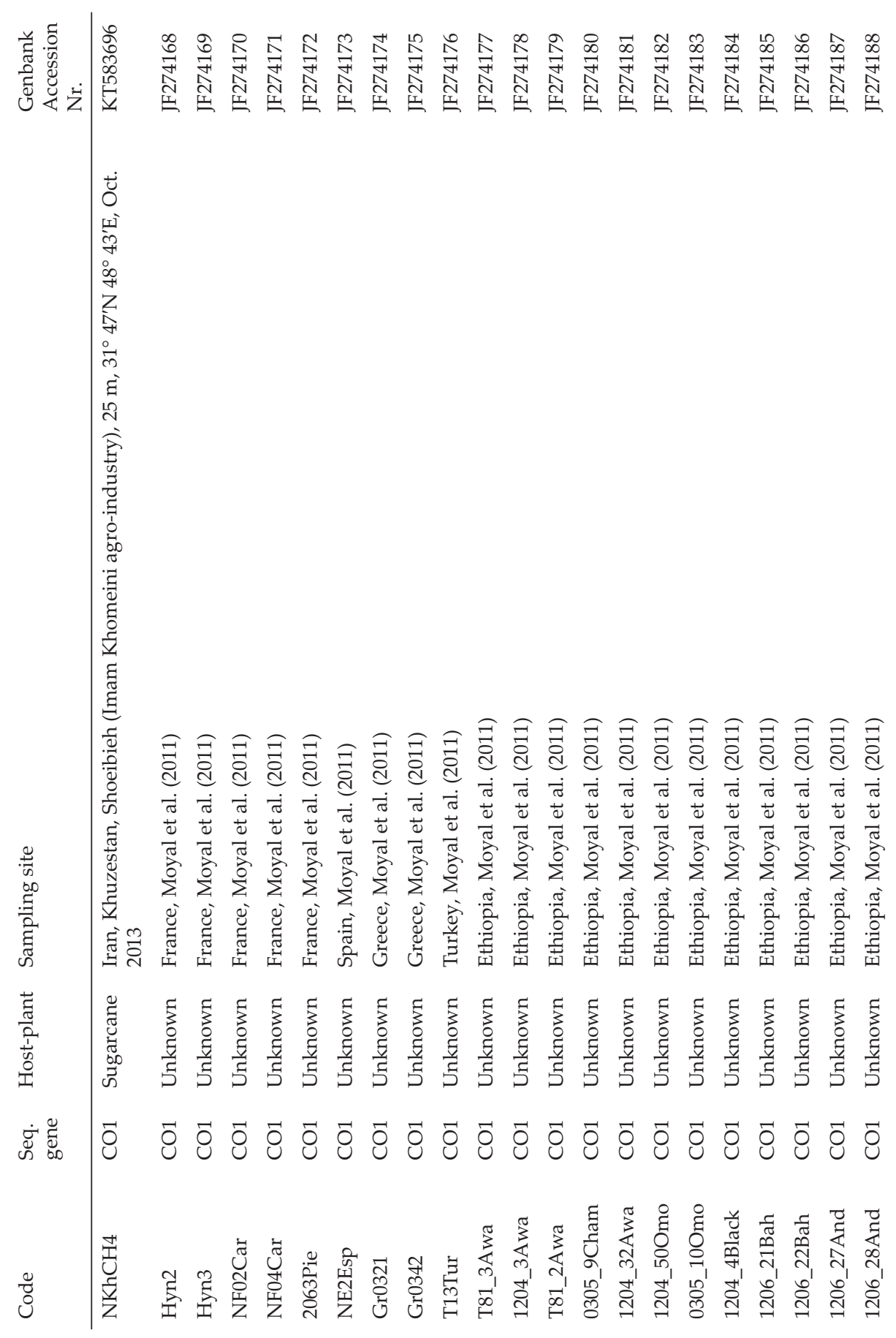




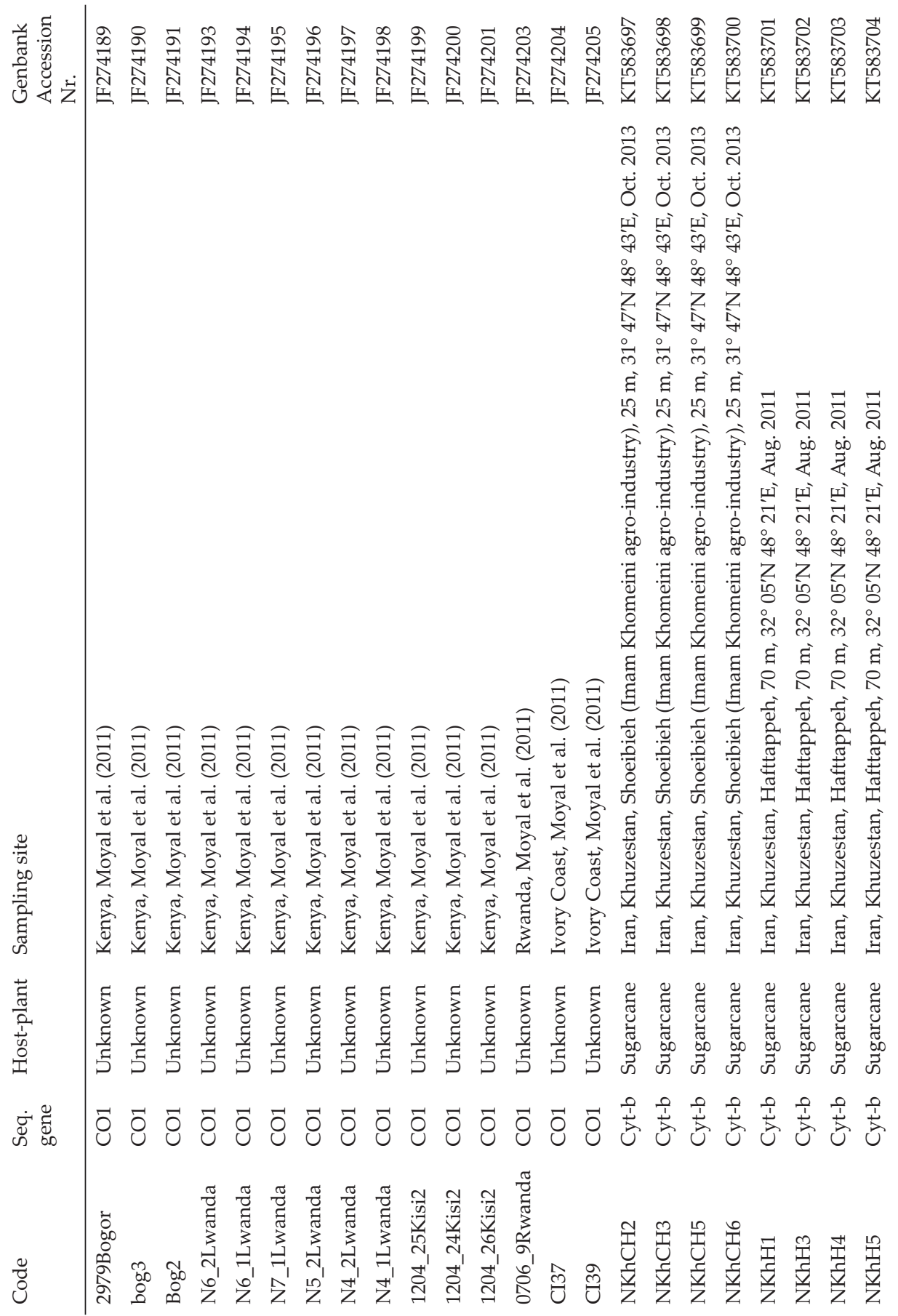




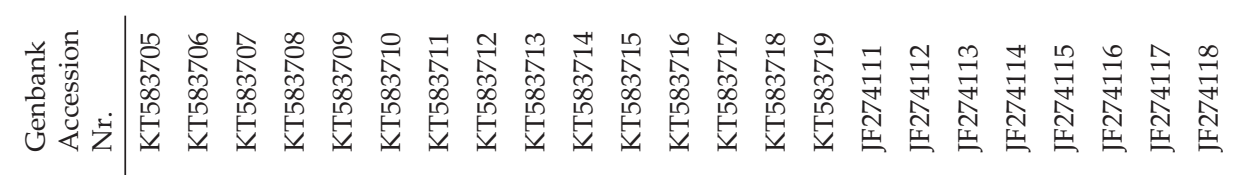

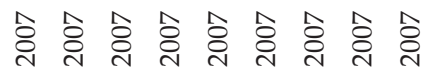

主主主主主主

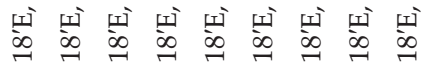

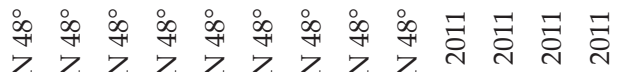

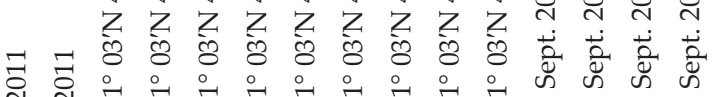

ते ते

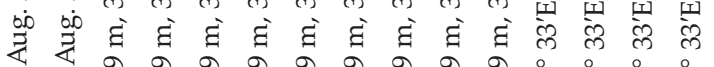

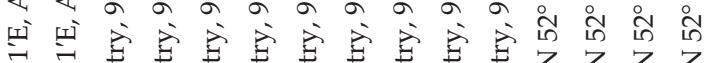

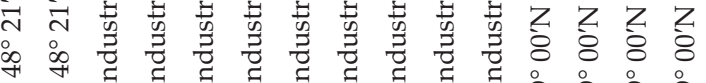

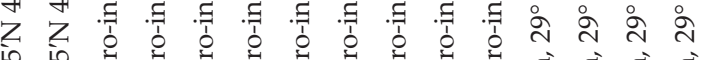

is i

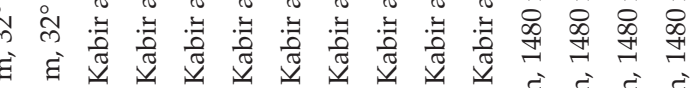

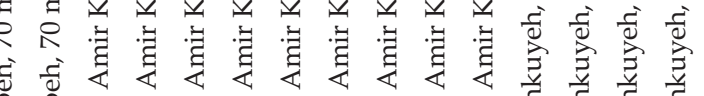

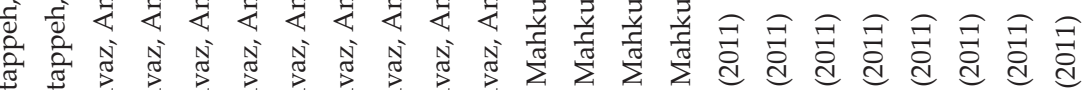

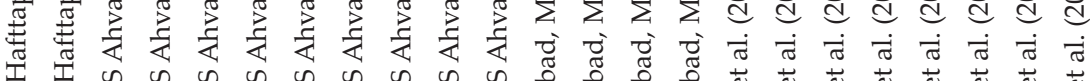

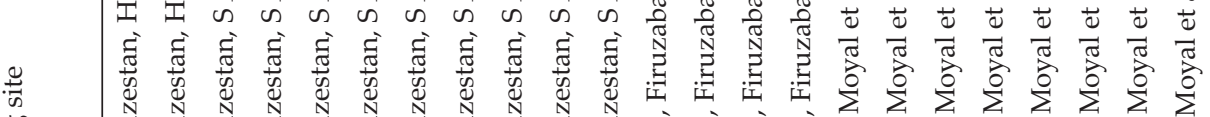

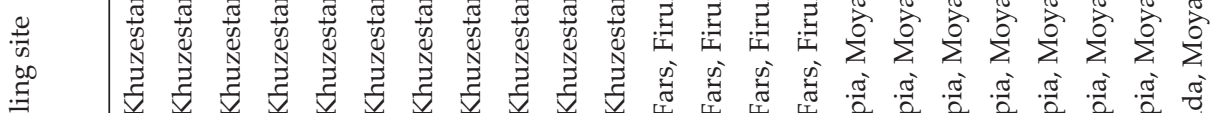

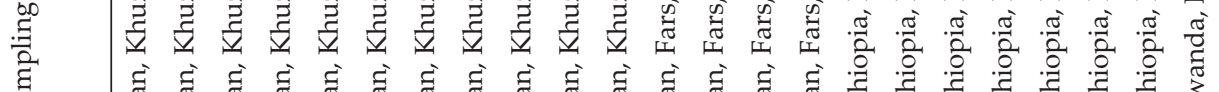

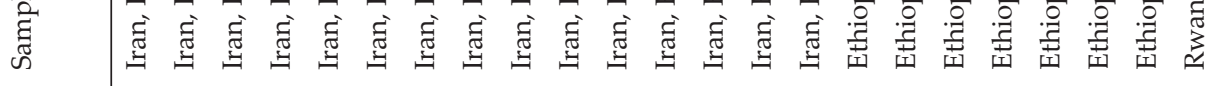

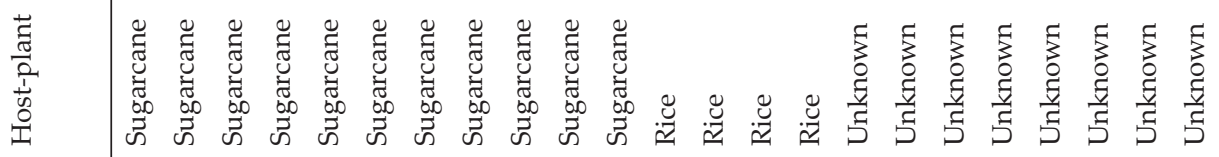

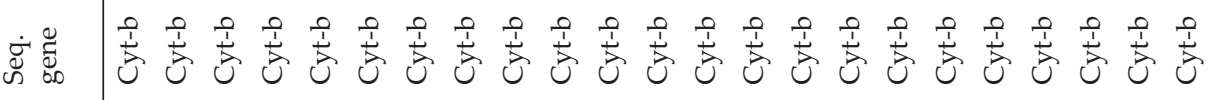

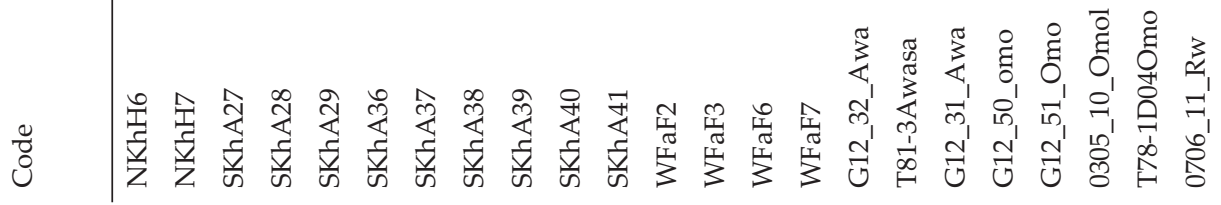




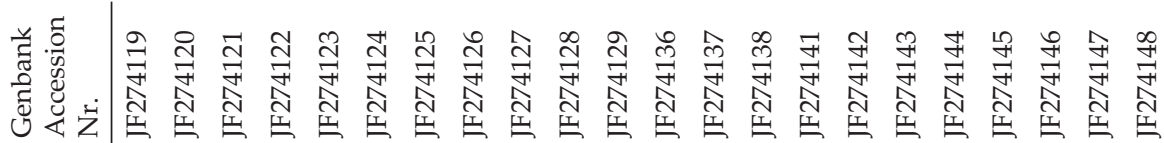

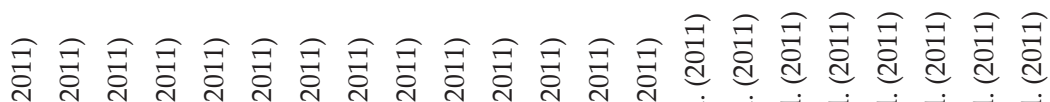

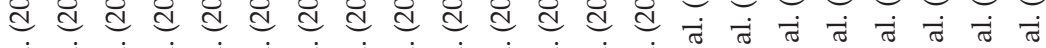

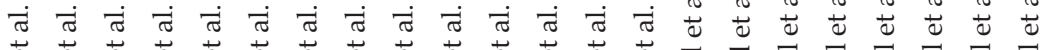

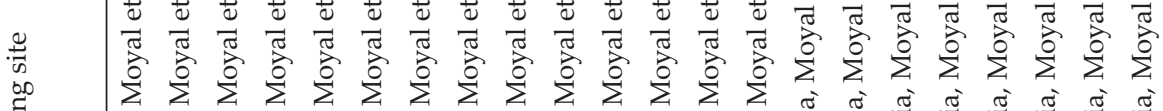

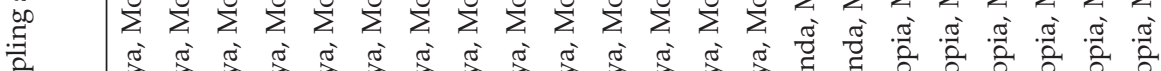
至

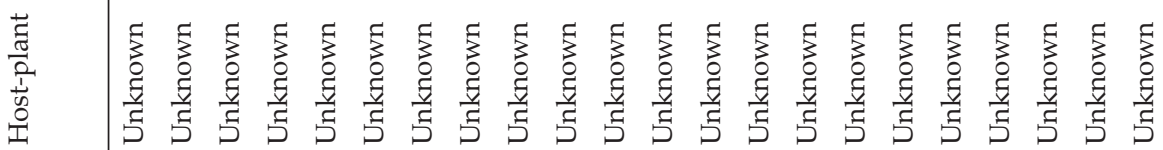

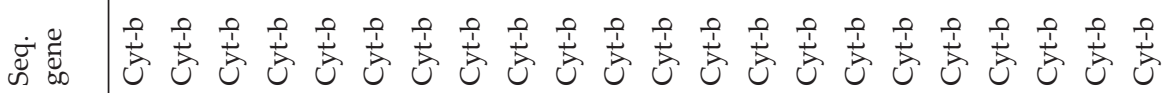

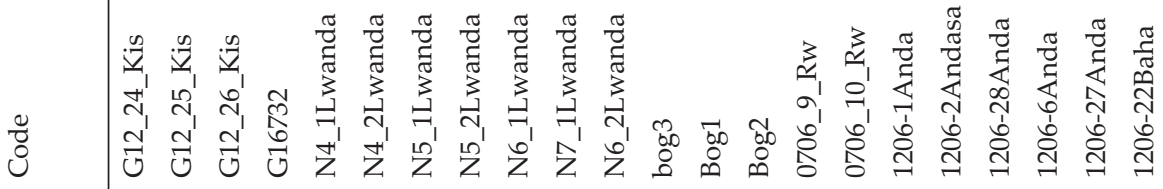




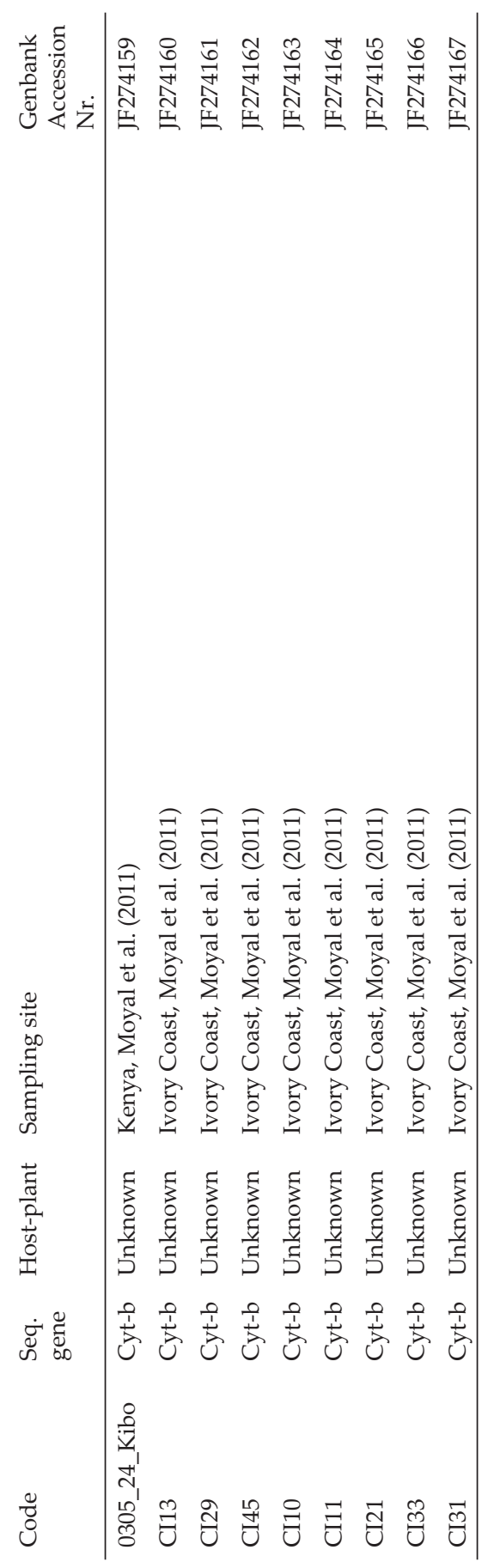

